\title{
2013/71
}

\section{Monopolistic competition and income dispersion}

Alexander Osharin, Jacques Thisse, Philip Ushchev and Valery Verbus

\section{DISCUSSION PAPER}

Center for Operations Research and Econometrics

Voie du Roman Pays, 34

B-1348 Louvain-la-Neuve

Belgium

http://www.uclouvain.be/core 


\title{
CORE DISCUSSION PAPER \\ 2013/71
}

\section{Monopolistic competition and income dispersion}

\author{
Alexander OSHARIN ${ }^{1}$, Jacques-François THISSE ${ }^{2}$, \\ Philip USHCHEV ${ }^{3}$ and Valery VERBUS ${ }^{4}$
}

December 2013

\begin{abstract}
We develop a model of monopolistic competition that accounts for consumers' heterogeneity in both incomes and preferences. This model makes it possible to study the implications of income redistribution on the toughness of competition. We show how the market outcome depends on the joint distribution of consumers' tastes and incomes and obtain a closed-form solution for a symmetric equilibrium. Competition toughness is measured by the weighted average elasticity of substitution. Income redistribution generically affects the market outcome, even when incomes are redistributed across consumers with different tastes in a way such that the overall income distribution remains the same.
\end{abstract}

Keywords: heterogenous consumers, income redistribution, toughness of competition, monopolistic competition.

JEL classification: D43, L11, L13.

\footnotetext{
${ }^{1}$ NRU-Higher School of Economics, Nizhniy Novgorod, Russia. E-mail: aosharin@hse.ru

2 Université catholique de Louvain, CORE, B-1348 Louvain-la-Neuve, Belgium; NRU-Higher School of Economics, Russia and CEPR.E-mail: Jacques.thisse@uclouvain.be

${ }^{3}$ NRU-Higher School of Economics, Russia.E-mail: ph.ushchev@gmail.com

${ }^{4}$ NRU-Higher School of Economics, Nizhniy Novgorod, Russia. E-mail: vverbus@hse.ru

We owe special thanks to one referee and to F. Mayneris for their insightful comments. We also thank R. Dos Santos, J. Markusen, J. Morrow, F. Robert-Nicoud, O. Shepotylo, A. Sidorova and D.-Z. Zeng for valuable suggestions. The financial support from the Government of the Russian Federation under the grant 11.G34.31.0059 is acknowledged.
} 


\section{Introduction}

The CES model of monopolistic competition developed by Dixit and Stiglitz (1977) has been applied successfully to a wide range of economic fields (Brakman and Heijdra, 2004). Yet, there is a growing discomfort with the assumption of identical consumers having homothetic preferences. For example, a great many trade papers still assume that consumers have identical CES preferences within and across countries. This assumption implies that market demand depends only upon prices and the aggregate income of each country. As a consequence, trade flows are viewed as independent of the income distribution within trading partners, which hardly seems plausible (Fajgelbaum et al., 2011; Markusen, 2013). To put it bluntly, a large share of the literature built on the CES model of monopolistic competition seems to ignore the basic microeconomic idea that income distribution (Hildenbrand, 1983) and preference heterogeneity (Grandmont, 1987) affect market demand and, as a consequence, the behavior of firms and the properties of the market equilibrium.

There are at least two ways to avoid this pitfall. In the first approach, individual preferences are non-homothetic and identical across consumers. Examples include Behrens and Murata (2007), Zhelobodko et al. (2012), and Bertoletti and Etro (2013). The second approach - the one adopted in this paper - is to introduce heterogeneity in consumers' tastes, while retaining the tractability provided by homothetic individual preferences. The reason why this approach may be conducive to new and relevant results is easy to pin down. As is well known, a necessary and sufficient condition for the market demand to depend solely on prices and the aggregate income is that individual consumers' preferences satisfy the Gorman form. If preferences are homothetic and non-identical across consumers, this condition fails to hold, which implies a non-trivial relationship between market demand and income inequality.

We build a simple model in which firms' demands, whence the market outcome, are affected by income inequality. More concretely, we propose a model of monopolistic competition in which consumer heterogeneity stems from two sources: tastes and individual incomes. The key feature of our approach is the difference between individual and market demands. The widely accepted assumption of consumers endowed with identical preferences makes these models unable to generate non-trivial aggregate effects in market behavior. In the same spirit as Melitz (2003), assuming heterogeneous consumers leads firms to face market demands that drastically differ from individual demands. Thus, heterogeneity in consumer preferences seems to be a fundamental ingredient that any model of monopolistic competition should take on board. We will see that the impact of income redistribution on the market outcome depends on how it affects the joint distribution of incomes and tastes, 
not just the income distribution. More precisely, prices, outputs and product diversity vary according to whether a redistributional income shock makes consumers endowed with high elasticities of substitution get richer or poorer after the redistribution. We will also show that an economy that grows richer need not enjoy more product diversity. Here also, the ultimate impact of rising incomes on the range of supplied varieties depends on how tastes and incomes are related.

Interestingly, the overall impact of income redistribution is captured through only one parameter - the weighted sum of individual elasticities of substitution, which depends on the joint distribution of tastes and incomes. This allows us to derive analytical results, unlike, for example, Yurko (2011) who has to run simulations in order to uncover the impact of income inequality on market prices and product diversity in the Gabszewicz and Thisse (1979) model of vertical differentiation.

Even though CES preferences are unable to reproduce several important empirical facts, we choose to work with such preferences because the new market demands we obtain exhibit appealing properties when consumers have different CES preferences. In addition, as long as we focus on redistributional income effects rather than market size effects, the CES assumption need not imply the empirical irrelevance of the model. Addressing the impact of income redistribution under non-homothetic preferences and heterogeneous consumers is beyond the scope of this paper.

To the best of our knowledge, our paper is the first one that brings together consumers' differences in incomes and tastes within the same framework. The two types of consumers' heterogeneity have been tackled separately in a handful of papers. Tarasov (2010) considers the effect of taste heterogeneity within a random utility setting and finds that the equilibrium price increases with individual consumer income. However, his model cannot be used to study the impact of income inequality, for individual incomes are the same across consumers. Di Comite et al. (2013) generalize the linear model of monopolistic competition by introducing consumer-specific horizontal and vertical differentiation parameters. However, their quasilinear setting does not allow studying the impact of income dispersion. In a two-sector model with one CES-differentiated good, Benassi et al. (2005) show that an increase in income dispersion leads to a lower number of varieties.

Foellmi and Zweimüller (2004) are closer to us. Using additive preferences, they show that an increase in income inequality leads to a higher (lower) market price and to more (less) product diversity if the inverse of the Arrow-Pratt measure of the per-variety utility is concave (convex) in the individual consumption level. Bertoletti and Etro (2013) use dually additive preferences and find that a mean-preserving spread decreases (increases) prices and the number of varieties when the demand elasticity is convex (concave) in price. In both 
cases, these conditions are independent of the income distribution. In contrast, our model highlights the role played by the interaction between income and taste heterogeneity in determining the market outcome. In particular, we show that the sign of the correlation between the two distributions is a key-factor in the market response to an income shock. In addition, we find that the equilibrium is affected by an income redistribution that keeps unchanged both total income and income variance across consumers. Therefore, the two approaches mentioned above are not equivalent.

The remaining of the paper is organized as follows. Section 2 describes the model. In Section 3 we derive a closed-form solution for the equilibrium outcome. Section 4 focuses on the impact of income redistribution on the market outcome, with a special emphasis on the toughness of competition. Section 5 concludes.

\section{The model}

The economy involves one sector supplying a horizontally differentiated good, one production factor - labor, and a unit population of heterogeneous consumers. The space of consumers $\Omega$ is endowed with a unit measure $\mu$. The labor market is competitive. We choose labor as the numéraire, which means that the price of one efficiency unit of labor is 1 . Consumers are endowed with different numbers of efficiency units of labor. Therefore, they have different incomes. The differentiated good is made available under the form of a continuum of varieties of measure $n>0$.

Unlike standard models of monopolistic competition, consumers are heterogeneous in both income and preferences. Income inequality stems from the assumption that consumers are endowed with different numbers of efficiency units of labor. Consumers have CES preferences but perceive varieties as being more or less differentiated. Formally, this means that the elasticity of substitution between any pair of varieties varies across consumers. In other words, the preference for variety is consumer-specific.

Consumer $\omega$ is thus fully characterized by a couple $(y(\omega), \sigma(\omega))$ where $y(\omega)>0$ is the consumer's income and $\sigma(\omega)>1$ the elasticity of substitution that captures how consumer $\omega$ perceives the differentiated varieties. In this context, the distribution of $\sigma(\cdot)$ across $(\Omega, \mu)$ may be viewed as the univariate taste distribution, while the distribution of $y(\cdot)$ is the univariate income distribution. The utility function of consumer $\omega$ is thus given by

$$
U(\omega, \mathbf{x}(\omega)) \equiv\left[\int_{0}^{n}\left(x_{i}(\omega)\right)^{(\sigma(\omega)-1) / \sigma(\omega)} \mathrm{d} i\right]^{\sigma(\omega) /(\sigma(\omega)-1)}
$$

Consumer $\omega$ maximizes her utility (1) subject to the budget constraint 


$$
\int_{0}^{n} p_{i} x_{i}(\omega) \mathrm{d} i \leq y(\omega)
$$

The demand of consumer $\omega$ for variety $i$ is given by

$$
x_{i}(\omega)=y(\omega) \frac{p_{i}^{-\sigma(\omega)}}{P(\omega)}
$$

where

$$
P(\omega) \equiv \int_{0}^{n} p_{j}^{1-\sigma(\omega)} \mathrm{d} j
$$

is the price index common to the consumers sharing the same elasticity of substitution. Inspecting (2) reveals that the individual income acts as a consumer-specific demand-shifter, while the expenditure share $p_{i} x_{i}(\omega) / y(\omega)$ on variety $i$ also varies across consumers.

Therefore, the aggregate demand faced by firm $i$ is given by

$$
q_{i}=\int_{\Omega} x_{i}(\omega) \mathrm{d} \mu=\int_{\Omega} \frac{y(\omega)}{P(\omega)} p_{i}^{-\sigma(\omega)} \mathrm{d} \mu .
$$

Firms do not observe the individual characteristics $y(\omega)$ and $\sigma(\omega)$ and, therefore, cannot price discriminate across consumers. Firms know only the demand functions (3). Unlike the individual demands (2), the market demand (3) is not isoelastic because $\sigma(\omega)$ varies across consumers. As a consequence, the market demand faced by every firm depends on the income and taste distribution. In the limiting case where consumers share the same preferences $(\sigma(\omega)=\sigma)$, the market demand is (i) isoelastic and (ii) linear in total income

$$
Y \equiv \int_{\Omega} y(\omega) \mathrm{d} \mu
$$

so that the way income is distributed across consumers has no impact on the market outcome.

Each variety is produced by a single firm and each firm produces a single variety. Because consumers are heterogeneous, we find it reasonable to restrict the analysis to the case of homogeneous firms, for otherwise it would be difficult to ascertain the effects triggered by the heterogeneity of each type of agent. Hence, firms share the same technology and produce under increasing returns. Let $f>0$ be the fixed requirement of labor and $c>0$ the marginal requirement needed to produce a variety. Since the price of an efficiency unit of labor is normalized to 1 , the cost of producing $q_{i}$ units of variety $i \in[0, n]$ is equal to $f+c q_{i}$.

Each firm maximizes its profits: 


$$
\pi\left(p_{i}\right)=\left(p_{i}-c\right) q_{i}-f=\int_{\Omega} \frac{y(\omega)}{P(\omega)}\left[p_{i}^{1-\sigma(\omega)}-c p_{i}^{-\sigma(\omega)}\right] \mathrm{d} \mu-f
$$

where the price index $P(\omega)$ and the bracketed term can no longer be factorized because they are consumer-specific. As a consequence, a firm's profits depend on the way the total income is distributed across consumers.

\section{The market equilibrium}

Applying the first-order condition to (4) yields the following equation:

$$
\frac{\mathrm{d} \pi}{\mathrm{d} p_{i}}=\int_{\Omega} \frac{y(\omega)}{P(\omega)}\left[(1-\sigma(\omega)) p_{i}^{-\sigma(\omega)}+c \sigma(\omega) p_{i}^{-\sigma(\omega)-1}\right] \mathrm{d} \mu=0 .
$$

Since firms are homogeneous, we focus on the symmetric equilibrium:

$$
p_{i}=p \text { for all } i \Rightarrow P(\omega)=n p^{1-\sigma(\omega)} .
$$

Combining (5) and (6) determines the equilibrium price common to all firms:

$$
p^{*}=\frac{\bar{\sigma}}{\bar{\sigma}-1} c
$$

where $\bar{\sigma}$ is the weighted average elasticity of substitution given by

$$
\bar{\sigma} \equiv \frac{\int_{\Omega} \sigma(\omega) y(\omega) \mathrm{d} \mu}{\int_{\Omega} y(\omega) \mathrm{d} \mu}>1 .
$$

Thus, unless consumers have the same attitude toward product differentiation, the market price $p^{*}$ depends on the income and taste distributions through the value of $\bar{\sigma}$. Note that, at any symmetric outcome, we also have

$$
\varepsilon=\bar{\sigma}
$$

where $\varepsilon$ is the price-elasticity of the market demand. Thus, in equilibrium the price elasticity of the aggregate demand for each variety is equal to the sum of the individual elasticities weighted by the individual income shares.

Free entry implies that firms' profits are zero. As a consequence, firms have the same equilibrium size given by

$$
q^{*}=\frac{f(\bar{\sigma}-1)}{c}
$$


which also depends on the income and taste distributions.

To pin down the equilibrium mass of firms, we integrate both sides of the budget constraints $\operatorname{pnx}(\omega)=y(\omega)$ across $\omega$ with respect to $\mu$, which yields

$$
n^{*}=\frac{Y}{\bar{\sigma} f} \text {. }
$$

The expressions (7), (9) and (10) are the same as those obtained in the Dixit-Stiglitz model provided that $\bar{\sigma}$ is the common elasticity of substitution. Since consumer heterogeneity is captured by the sole parameter $\bar{\sigma}$, our modeling strategy thus allows retaining the tractability of the Dixit-Stiglitz model. In addition, very much like the common elasticity of substitution in this model, the weighted average elasticity of substitution $\bar{\sigma}$ may be viewed as a measure of the toughness of competition in a setting in which individual tastes and income are heterogeneous. Note also that our model can easily be extended to accommodate heterogeneous firms à la Melitz (2003), thus allowing one to treat consumers' and firms' heterogeneity within the same simple setting.

Thus, everything seems to work as in the standard setting in which consumers would share the elasticity of substitution $\bar{\sigma}$. What is new is that $\bar{\sigma}$ varies with the joint distribution of $y$ and $\sigma$. The above expressions also imply that, by increasing (decreasing) the value of $\bar{\sigma}$, an income redistribution may generate very contrasted effects, which take the concrete form of higher (lower) prices and more (less) product diversity. In the next section, we will state a sufficient condition on the joint taste and income distribution for each type of effect to arise.

Note, finally, that weighting varieties in the CES, like in Hallack (2006), is not an alternative to our modelling approach. Indeed, if individual preferences are given by

$$
U(\omega, \mathbf{x}(\omega)) \equiv \int_{0}^{n} \alpha_{i}(\omega)\left(x_{i}(\omega)\right)^{(\sigma-1) / \sigma} \mathrm{d} i
$$

where $\alpha_{i}(\omega)>0$ expresses a particular consumer's intensity of preference for variety $i$, it can be shown that all firms charge the same price $\sigma c /(\sigma-1)$, which is independent of the income distribution and of the number of firms. Thus, unlike (7), introducing the salience coefficients $\alpha_{i}(\omega)$ has no impact on the equilibrium price, which remains independent of the income distribution and the number of firms. However, total profits are not equal to zero anymore and the way they are distributed across consumers affects the income distribution. 


\section{Income redistribution matters}

This section addresses the main issue of our paper: Does income redistribution affect the toughness of competition? When consumers have homogeneous tastes, the answer is known to be negative because only the total income matters. In contrast, when consumers have heterogeneous tastes, the answer is positive, the reason being that consumers' tastes and income interact to determine firms' demands given by (3). The crucial point in understanding our results is that the market outcome is affected by the joint distribution of taste and income, not just by the income distribution.

It turns out to be analytically convenient and intuitively appealing to use the language of probability theory, reinterpreting the variables $y$ and $\sigma$ as two random variables, $Y$ and $S{ }^{1}$ In this context, the expression (8) can be rewritten as follows:

$$
\bar{\sigma}=\frac{\mathbf{E}(S Y)}{\mathbf{E}(Y)}
$$

where $\mathbf{E}$ is the expectation operator defined over $L_{2}(\Omega, \mu)$. Since $\mathbf{E}(S Y)=\operatorname{cov}(S, Y)+$ $\mathbf{E}(Y) \mathbf{E}(S)$, where $\operatorname{cov}(S, Y)$ is the covariance between $Y$ and $S$, we may use (11) to obtain

$$
\bar{\sigma}=\mathbf{E}(S)+\frac{\operatorname{cov}(S, Y)}{\mathbf{E}(Y)}=\mathbf{E}(S)+\frac{\sqrt{\mathbf{V}(S) \mathbf{V}(Y)}}{\mathbf{E}(Y)} \operatorname{corr}(S, Y)
$$

where $\operatorname{corr}(S, Y)$ is the correlation coefficient between $Y$ and $S$ while $\mathbf{V}$ is the variance operator over $L_{2}(\Omega, \mu)$.

The expression (12) shows that the way incomes and tastes are related has an impact on the market outcome. More precisely, the weighted average elasticity of substitution, hence the toughness of competition on the product market, is determined only by the first two moments of the income-taste distribution and by the correlation between these two variables.

The following proposition is an immediate consequence of (12).

Proposition. Assume a given taste distribution and a mean-and-variance-preserving redistribution of income. Then, competition gets tougher (softer) if and only if the correlation coefficient between consumers' incomes and preferences for variety increases (decreases). Furthermore, the market outcome is unaffected if and only if these two variables are uncorrelated.

The economic intuition behind this proposition is easy to grasp. When incomes and tastes are correlated, a redistribution of income toward consumers endowed with high (low) elasticities of substitution implies that these consumers account for a larger share of the

\footnotetext{
${ }^{1}$ We assume that $Y, S \in L_{2}(\Omega, \mu)$, for otherwise the correlation between $Y$ and $S$, which plays a key role in our analysis, need not be defined.
} 
total demand than before redistribution. This leads to a higher (lower) value of $\bar{\sigma}$, hence to tougher (softer) competition. It then follows from (7), (9) and (10) that firms get bigger (smaller) and price their varieties at a lower (higher) level while the market involves less (more) product diversity. What is less straightforward is that a redistribution that leaves unchanged the mean and standard-deviation of the income distribution has an impact on firms' market power. Since income redistribution may a priori increase or decrease the correlation between tastes and incomes, making predictions about the impact of a shock on income distribution seems to be a hard task, the reason being that this impact depends on individual preferences, which are not observable.

To illustrate how the interaction between the two distributions affects the market outcome, consider the following numerical example. There are two classes of consumers. The first one contains two consumers ( 1 and 2$)$, while the second one involves three consumers $(3$, 4 and 5). Each consumer belonging to the first (second) class has preferences described by $\sigma_{1}$ $\left(\sigma_{2}\right)$ and owned $10(100)$ units of the numéraire. After redistribution, 1 and 2 own 100 units of the numéraire, 3 and 4 have an income equal to 10 units, whereas consumer 5 is unaffected. The share of consumers having 10 and 100 units of the numéraire is still equal to 2/5 and $3 / 5$, respectively. Consequently, the income distribution does not change. However, computing the correlation coefficient before (after) redistribution yields $\operatorname{corr}(Y, S)=\operatorname{sign}\left(\sigma_{2}-\sigma_{1}\right)$ $\left(\operatorname{corr}(Y, S)=-2 / 3 \operatorname{sign}\left(\sigma_{2}-\sigma_{1}\right)\right)$. This means that the income redistribution generates a drop (hike) equal to $5 / 3$ in the correlation coefficient when $\sigma_{2}>\sigma_{1}\left(\sigma_{2}<\sigma_{1}\right)$, thus leading to less (more) competition in the product market.

Thus, even in the extreme case in which both the univariate income and taste distributions remain the same, income redistribution may affect the joint distribution of $(Y, S)$. More generally, provided that the income redistribution does not affect the first two moments of the income distribution, i.e. its mean and variance, the above proposition states that the market outcome changes solely with the correlation between $Y$ and $S$.

In addition, (12) has further implications that confirm the interest of our approach for studying the impact of income dispersion. We first consider a mean-preserving income redistribution given by

$$
y(\omega) \rightarrow \mathbf{E}(Y)+(1-t)(y(\omega)-\mathbf{E}(Y))
$$

where $t \in(0,1)$ is the income tax rate. Observe that the tax revenue becomes a subvention income when the consumer's gross income is smaller than the average income. Such an income redistribution among consumers reduces the variance $\mathbf{V}(Y)$ by factor $(1-t)^{2}$. Since the correlation coefficient is invariant to an affine transformation such as (13), we have:

Corollary 1. Assume an income redistribution given by (13). Then, competition gets tougher (softer) if incomes and individual preferences for variety are negatively (positively) 
correlated.

This corollary may be viewed as the counterpart of Foellmi and Zweimüller's (2004) result mentioned in the introduction which, unlike ours, does not involve the income distribution. It is also consistent with Yurko (2011) who showed in a very different setting that a growing income inequality leads to a widening range of vertically differentiated varieties.

The last two corollaries refer to the effects of growing incomes.

Corollary 2. Assume that all incomes increase by the same amount, $y(\omega) \rightarrow y(\omega)+\Delta$, where $\Delta>0$ is a constant. Then, competition gets softer (tougher) if incomes and individual preferences for variety are negatively (positively) correlated.

Thus, depending on consumers' attitude toward product differentiation, a uniform income hike may have opposite effects on both market prices and product diversity.

Corollary 3. Assume a proportional increase of incomes: $y(\omega) \rightarrow(1+r) y(\omega)$ where $r>0$ is constant. Then, the equilibrium price and firm size remain the same regardless of the value of $r$, while the equilibrium number of firms increases by factor $1+r$.

In other words, a proportional income growth triggers more product diversity, but does not affect market prices. Corollaries 2 and 3 show that higher incomes may have very different impacts on the market outcome depending on the way individual incomes rise. This is to be contrasted with Tarasov (2010) who finds that under weak restrictions on the taste distribution an increase in consumers' income relaxes competition. This difference in findings highlights the importance of working with both types of heterogeneity to derive robust results.

\section{$5 \quad$ Concluding remarks}

We have developed a simple model of monopolistic competition with heterogeneous consumers in which firms do not face isoelastic demands. It has (at least) two main implications. First, we show that introducing taste and income heterogeneity need not result in analytical intractability. Although very simple, our model exhibits a wide range of predictions regarding the impact of income redistribution on the market outcome. The main reason for this is that tastes and incomes are not related in a way that seems compelling. ${ }^{2}$ In the last analysis, determining the sign of the correlation coefficient and how this coefficient varies with the income and taste distributions is an empirical issue. For example, we may expect the calibration of CGE models to shed light on the relationships between the two distributions once these models recognize that consumers belonging to different socioeconomic classes

\footnotetext{
${ }^{2}$ Research in genetics suggests the existence of a novelty-seeking gene (Benjamin et al., 1996). It would be interesting to investigate the implications of this gene for variety-seeking behavior.
} 
may have different preferences over the same goods. Second, our model brings to the fore a new effect of redistributive policies: a policy that aims to reduce income disparities has a positive or negative impact on the toughness of competition, and thus affects consumers' welfare through a new channel that has been largely ignored until now. In particular, by affecting the extent of product variety, income redistribution generates an indirect effect that magnifies or conflicts with the direct effect of the redistribution policy.

Our model retains the tractability of the standard CES model. For this reason, we believe that it can be used to revisit several issues where the Dixit-Stiglitz model has been applied. One example that suggests itself is trade theory where the assumption of identical CES consumers implies that the demand for different goods is the same within the same country, while the demand for the same good sold across different countries is also the same. These restrictive assumptions have led scholars to introduce firm-destination random shocks to match features of the data (see, e.g. Bernard et al., 2011). In this respect, our model provides a richer micro-founded alternative to what looks like a deus ex machina. In addition, the model can be used to uncover new effects of redistributive taxation policies as well as the impacts of income transfers between rich and poor regions on the working of regional product markets, hence that of local labor markets.

\section{References}

[1] Behrens, K. and Murata, Y., 2007. General equilibrium models of monopolistic competition: a new approach. Journal of Economic Theory 136, 776-787.

[2] Benassi, C., Chirco, A. and Colombo, C., 2005. A model of monopolistic competition with personal income dispersion. Metroeconomica 56, 305-317.

[3] Benjamin, J., Li, L., Patterson, C., Greenberg, B.D., Murphy, D.L. and Hamer, D.H., 1996. Population and familial association between the D4 dopamine receptor gene and measures of novelty seeking. Nature genetics 12 , 81-84.

[4] Bernard, A.B., Redding, S. and Schott, P., 2011. Multi-product firms and trade liberalization. Quarterly Journal of Economics 126, 1271-1318.

[5] Bertoletti, P. and Etro, F., 2013. Monopolistic competition when income matters. DEM Working Papers Series 043, University of Pavia, Department of Economics and Management.

[6] Brakman, S. and Heijdra, B.J., 2004. The Monopolistic Competition Revolution in Retrospect. Cambridge: Cambridge University Press. 
[7] Di Comite, F., Thisse, J.-F. Thisse and Vandenbussche, H., 2013. Verti-zontal differentiation in export markets. CORE Discussion Paper N²013/65.

[8] Dixit, A. and Stiglitz, J., 1977. Monopolistic competition and optimum product diversity. American Economic Review 67, 297-308.

[9] Fajgelbaum, P., Grossman, G.M. and Helpman, E., 2011. Income distribution, product quality, and international trade. Journal of Political Economy 119, 721-765.

[10] Foellmi, R. and Zweimüller, J., 2004. Inequality, market power, and product diversity. Economics Letters 82, 139-145.

[11] Gabszewicz, J.J. and Thisse, J.-F., 1979. Price competition, quality and income disparities. Journal of Economic Theory 20, 340-59.

[12] Grandmont, J.-M., 1987. Distributions of preferences and the "Law of Demand." Econometrica 55, 155-161.

[13] Hallak, J.C., 2006. Product quality and the direction of trade. Journal of International Economics 68, 238 - 265.

[14] Hildenbrand, W., 1983. On the "Law of Demand." Econometrica 51, 997-1019.

[15] Markusen, J.R., 2013. Putting per-capita income back into trade theory. Journal of International Economics 90, 255-265.

[16] Melitz, M.J., 2003. The impact of trade on intraindustry reallocations and aggregate industry productivity. Econometrica 71, 1695-1725.

[17] Tarasov, A., 2010. Consumer preferences in monopolistic competition models. Munich Discussion Paper No. 2010-25.

[18] Yurko, A.V, 2011. How does income inequality affect market outcomes in vertically differentiated markets? International Journal of Industrial Organization 29, 493-503.

[19] Zhelobodko, E., Kokovin, S., Parenti, M. and Thisse, J.-F., 2012. Monopolistic competition: beyond the constant elasticity of substitution. Econometrica 80, 2765-2784. 


\section{Recent titles}

\section{CORE Discussion Papers}

2013/33 Georg KIRCHSTEIGER, Marco MANTOVANI, Ana MAULEON and Vincent VANNETELBOSCH. Limited farsightedness in network formation.

2013/34 Ana MAULEON and Vincent VANNETELBOSCH. Relative concerns and delays in bargaining with private information.

2013/35 Kristof BOSMANS, Koen DECANCQ and Erwin OOGHE. What do normative indices of multidimensional inequality really measure?

2013/36 Alain PHOLO BALA, Dominique PEETERS and Isabelle THOMAS. Spatial issues on a hedonic estimation of rents in Brussels.

2013/37 Lionel ARTIGE, Antoine DEDRY and Pierre PESTIEAU. Social security and economic integration.

2013/38 Nicolas BOUCKAERT and Erik SCHOKKAERT. Differing types of medical prevention appeal to different individuals.

2013/39 Pierre M. PICARD. Trade, economic geography and the choice of product quality.

2013/40 Tanja B. MLINAR and Philippe CHEVALIER. Pooling in manufacturing: do opposites attract?

2013/41 Chiara CANTA and Marie-Louise LEROUX. Public and private hospitals, congestion, and redistribution.

2013/42 Mathieu LEFEBVRE, Pierre PESTIEAU and Gregory PONTHIERE. FGT poverty measures and the mortality paradox: Theory and evidence.

2013/43 Nada BELHADJ, Jean J. GABSZEWICZ and Ornella TAROLA. Social awareness and duopoly competition.

2013/44 Volker BRITZ, P. Jean-Jacques HERINGS and Arkadi PREDTETCHINSKI. On the convergence to the Nash bargaining solution for action-dependent bargaining protocols.

2013/45 Pasquale AVELLA, Maurizio BOCCIA and Laurence WOLSEY. Single item reformulations for a vendor managed inventory routing problem: computational experience with benchmark instances.

2013/46 Alejandro LAMAS, Tanja MLINAR, Liang LU and Philippe CHEVALIER. Revenue management for operations with urgent orders.

2013/47 Helmuth CREMER, Firouz GAHVARI and Pierre PESTIEAU. Uncertain altruism and the provision of long term care.

2013/48 Claire DUJARDIN, Vincent LORANT and Isabelle THOMAS. Self-assessed health of elderly people in Brussels: does the built environment matter?

2013/49 Marc FLEURBAEY, Marie-Louise LEROUX, Pierre PESTIEAU and Grégory PONTHIERE. Fair retirement under risky lifetime.

2013/50 Manuel FÖRSTER, Ana MAULEON and Vincent VANNETELBOSCH. Trust and manipulation in social networks.

2013/51 Anthony PAPAVASILIOU, Yi HE and Alva SVOBODA. Self-commitment of combined cycle units under electricity price uncertainty.

2013/52 Ana MAULEON, Elena MOLIS, Vincent VANNETELBOSCH and Wouter VERGOTE. Dominance invariant one-to-one matching problems.

2013/53 Jean GABSZEWICZ and Skerdilajda ZANAJ. (Un)stable vertical collusive agreements.

2013/54 François MANIQUET and Massimo MORELLI. Approval quorums dominate participation quorums.

2013/55 Mélanie LEFÈVRE and Joe THARAKAN. Intermediaries, transport costs and interlinked transactions.

2013/56 Gautier M. KRINGS, Jean-François CARPANTIER and Jean-Charles DELVENNE. Trade integration and the trade imbalances in the European Union: a network perspective.

2013/57 Philip USHCHEV, Igor SLOEV and Jacques-François THISSE. Do we go shopping downtown or in the 'burbs'? Why not both?

2013/58 Mathieu PARENTI. Large and small firms in a global market: David vs. Goliath.

\section{Recent titles}




\section{CORE Discussion Papers - continued}

2013/59 Paul BELLEFLAMME and Francis BLOCH. Dynamic protection of innovations through patents and trade secrets.

2013/60 Christian HAEDO and Michel MOUCHART. Specialized agglomerations with areal data: model and detection.

2013/61 Julien MARTIN and Florian MAYNERIS. High-end variety exporters defying distance: micro facts and macroeconomic implications.

2013/62 Luca G. DEIDDA and Dimitri PAOLINI. Wage premia, education race, and supply of educated workers.

2013/63 Laurence A. WOLSEY and Hande YAMAN. Continuous knapsack sets with divisible capacities.

2013/64 Francesco DI COMITE, Jacques-François THISSE and Hylke VANDENBUSSCHE. Vertizontal differentiation in export markets.

2013/65 Carl GAIGNÉ, Stéphane RIOU and Jacques-François THISSE. How to make the metropolitan area work? Neither big government, nor laissez-faire.

2013/66 Yu. NESTEROV and Vladimir SHIKHMAN. Algorithmic models of market equilibrium.

2013/67 Cristina PARDO-GARCIA and Jose J. SEMPERE-MONERRIS. Equilibrium mergers in a composite good industry with efficiencies.

2013/68 Federica RUSSO, Michel MOUCHART and Guillaume WUNSCH. Confounding and control in a multivariate system. An issue in causal attribution.

2013/69 Marco DI SUMMA. The convex hull of the all-different system with the inclusion property: a simple proof.

2013/70 Philippe DE DONDER and Pierre PESTIEAU. Lobbying, family concerns and the lack of political support for estate taxation.

2013/71 Alexander OSHARIN, Jacques-François THISSE, Philip USHCHEV and Valery VERBUS. Monopolistic competition and income dispersion.

\section{Books}

V. GINSBURGH and S. WEBER (2011), How many languages make sense? The economics of linguistic diversity. Princeton University Press.

I. THOMAS, D. VANNESTE and X. QUERRIAU (2011), Atlas de Belgique - Tome 4 Habitat. Academia Press.

W. GAERTNER and E. SCHOKKAERT (2012), Empirical social choice. Cambridge University Press.

L. BAUWENS, Ch. HAFNER and S. LAURENT (2012), Handbook of volatility models and their applications. Wiley.

J-C. PRAGER and J. THISSE (2012), Economic geography and the unequal development of regions. Routledge.

M. FLEURBAEY and F. MANIQUET (2012), Equality of opportunity: the economics of responsibility. World Scientific.

J. HINDRIKS (2012), Gestion publique. De Boeck.

M. FUJITA and J.F. THISSE (2013), Economics of agglomeration: cities, industrial location, and globalization. ( $2^{\text {nd }}$ edition). Cambridge University Press.

J. HINDRIKS and G.D. MYLES (2013). Intermediate public economics. ( $2^{\text {nd }}$ edition). MIT Press.

J. HINDRIKS, G.D. MYLES and N. HASHIMZADE (2013). Solutions manual to accompany intermediate public economics. ( $2^{\text {nd }}$ edition). MIT Press.

\section{CORE Lecture Series}

R. AMIR (2002), Supermodularity and complementarity in economics.

R. WEISMANTEL (2006), Lectures on mixed nonlinear programming.

A. SHAPIRO (2010), Stochastic programming: modeling and theory. 